\title{
Estimation of Soil Carbon Stock in Taiwan Arable Soils by Using Legacy Database and Digital Soil Mapping
}

\author{
Chun-Chih Tsui, Horng-Yuh Guo and \\ Zueng-Sang Chen \\ Additional information is available at the end of the chapter \\ http://dx.doi.org/10.5772/53211
}

\section{Introduction}

Since the Kyoto Protocol [1] was adopted, recent concerns about global warming have driven many effort been paid to develop methods to quantify both current and future carbon $(\mathrm{C})$ stocks in different ecosystems. In global assessment, the current $C$ stock contained in the plant and microbial biomass is estimated $560 \mathrm{Gt}$ and $110 \mathrm{Gt}$, respectively, while soil C pool amounts to $2500 \mathrm{Gt}$, includes $1550 \mathrm{Gt}$ of soil organic carbon (SOC) and $950 \mathrm{Gt}$ of soil inorganic carbon (SIC) [2-6]. The soil C pool is 3.3 times the size of the atmospheric C pool of 760 Gt and 4.5 times of the biotic pool [4]. Therefore, soils are particularly important, as they are the largest reservoir of $C$ in the terrestrial biosphere [2-3]. The SOC pool represent a dynamic equilibrium of $C$ gains from plant production and loss through decomposition [7-8]. Carbon stock in soils is influenced by climate condition, soil properties, vegetation, land use and soil management [9-13].

Vegetation is the only source of carbon to the soils in terrestrial ecosystems. Therefore, land use play a major role in SOC stock built up through organic matter input [14]. At time scale of decades to centuries, changes in land use can exert a major influence on soil C storage [15]. Researches indicated that SOC decreases following the conversion of native ecosystems (forests, shrublands, grasslands) to agriculture [10-11,16-19], for example, losses of SOC from the conversion of prairie to agriculture have resulted in 24 to $89 \%$ loss in North America [20-21]. Agricultural activities that result in depletion of the soil C pool include the followings [22]:

1. deforestation, biomass burning and other activities related to conversion of natural to agricultural ecosystems, 
2. tillage and other soil disturbances,

3. drainage of wetlands,

4. cultivation of organic soils,

5. removal of biomass for fuel, fodder and other uses, and

6. acceleration of soil erosion.

Besides, the magnitude and rate of SOC loss due to agricultural activities is higher for soils with a high $\mathrm{C}$ pool compared to a low $\mathrm{C}$ pool, tropics compared to temperature regions, croplands compared to pastures and tree plantations [22].

In agricultural soils, crop sequence, tillage and fertilization change inputs and outputs and, consequently the whole C dynamics. Potential soil C storage of the United States associated with changes in agricultural soil management [23]. In Java, Indonesia, SOC content declined from $2 \%$ to $0.75 \%$ in 1960 due to rapid conversion of natural vegetation to agricultural farms in the 1930s, but agricultural practices have started to accumulated soil C from 1975 to current, suggesting that the human or management influence on SOC stock can be stronger than the environmental factors [24]. In the United States, conversions of dry land farming to irrigated agriculture may increase SOC content in the soil profile with an average rate of 100 $\mathrm{kg} \mathrm{ha}^{-1} \mathrm{yr}^{-1}$ [23]. Long-term experiments in the Philippines showed that continuous cultivation of irrigated rice with balanced fertilization on submerged soils maintained or slightly increased SOC [25]. The previous study [26] indicated that soils with low to intermediate organic matter levels often exhibit a linear relationship between soil $\mathrm{C}$ levels and $\mathrm{C}$ inputs from addition of crop residues. The other study [27] found higher SOC content in 0-10 cm topsoil in sugarcane fields than that of Curatella savanna. These inconsistent results can be partly explained by the complexity of SOC, which consists of several pools that have a wide variety range of chemical properties and turnover times and consequently respond differently to land use changes [12].

The island of Taiwan used to be named as Formosa, which means "Beautiful Island". Forest lands cover about 2/3 of the total area of Taiwan. Since the first Han People arriving Taiwan from mainland China in the Qing Dynasty, most lowland forests have been exploited to agricultural lands. At present, a substantial conversion of cropland to urban land and other uses in Taiwan has occurred in recent decades. Consequently, these conversions have great impacts on SOC stock. Previous study [28] indicated that in the forest soils of Taiwan, the average SOC stock, estimated from 63 soil profiles excluding Histosols and Spodosols, was $18.5 \mathrm{~kg} \mathrm{~m}^{-2}$ in the upper $100 \mathrm{~cm}$ depth. Meanwhile in the arable land, using 140 soil profiles to estimate the SOC stock indicated that $5.97,8.06$ and $11.0 \mathrm{~kg} \mathrm{~m}^{-2}$ of $\mathrm{C}$ storages to the soil depth of 0-30, 0-50 and 0-100 cm, respectively [29]. Therefore, the conversion of forest land to rural soils has resulted in SOC loss in Taiwan.

According to the Kyoto Protocol, national householders need to pay attention on the impacts of land use changes on SOC storage in soils and vegetations. Any national soil-C-monitoring system must incorporate land use change as a key factor controlling changes in soil C [15]. However, monitoring long-term trends in SOC over a large geographical area is rare; 
furthermore, the slow rate of changes and large spatial variation in SOC require high sampling densities with sufficient time to observe the changes [24]. This means monitoring SOC for large areas is only available in countries with big monitoring infrastructure. In Taiwan, we still have no formal soil monitoring network yet, but there have been several soil survey projects on agricultural soils for various purposes by Taiwan Agricultural Research Institute (TARI), Council of Agriculture, Taiwan. Therefore, legacy soil survey data is our best resource to monitor the dynamics of soil C [24]. To evaluate the effect of changes in land use on SOC stocks, we use a relatively intensive datasets obtained in 2006 as a reference to former data or to future work. The aims of this study are

1. to estimate the SOC stock at different depths in arable soils of three counties with different soil characteristics and

2. to show the SOC stocks at different depth from surface to $150 \mathrm{~cm}$ by digital soil mapping techniques for three important agricultural counties in Taiwan.

\section{Materials and Methods}

\subsection{Pedotransfer function (PTF)}

Pedotransfer functions (PTFs) [30] is the predictive functions of some soil properties from other easily, routinely, or cheaply measured properties. PTFs have recently become a popular topic in soil science, and different types of function have been developed to predict physical or chemical soil properties. Soil bulk density $(\mathrm{Bd})$ measurements are often required as an important input parameter for various predictive and descriptive soil models. It is the mass of an oven-dry sample of undisturbed soil per unit bulk volume [31], and it is essential for weight-to volume or area conversions and is indispensable for the assessment of soil carbon stocks and nutrient pools [32]. Field sampling and measurement of bulk density are expensive, labor intensive and time-consuming [33-34]. Bulk density measurements are frequently missing from soil database or have been measured using different procedures [35]. To overcome this problem, PTFs are frequently used to estimate bulk density.

PTFs based on organic matter (OM) and soil texture are often used to estimate bulk density [33-39]. Besides, bulk density has been found to vary with depth, major soil group, water content, land use and vegetation [33,35,37-38,40]. Because published PTFs for bulk density have limited predictive potentials due to their development on specific soils and/or ecosystems [34], and there has been no PTFs for arable soils of Taiwan, we use legacy soil survey data to develop a PTF for estimating bulk density in this study.

\subsection{Dataset for developing the pedotransfer function (PTF)}

The dataset used for developing the PTF in this study included 230-horizon samples which were collected from arable soils located in Taoyuan and Tainan between 2001 to 2002. Field sampling was conducted following the Soil Survey Manual [41]. Analytical procedures used to measure the soil physical (e.g. bulk density) and chemical (e.g. SOC content) properties 
were described in the Soil Survey Laboratory Investigations Report No. 42 [42]. According to the location and field description of the profile, we could find its corresponding soil series in Soil Survey Report of Taoyuan and Tainan [43-44], respectively, which were published in 1970s by TARI. Soil texture (sand, silt and clay\%) and $\mathrm{pH}$ values of horizons were obtained from the Soil Survey Report. Table 1 lists the basic information of 230 soil samples.

\begin{tabular}{llll}
\hline Soil property & Data range & $\begin{array}{l}\text { Mean } \pm \text { Standard } \\
\text { deviation }\end{array}$ & Lab method/Description \\
\hline Profile depth $(\mathrm{cm})$ & $20-150$ & $70 \pm 33$ & \\
\hline $\mathrm{Bd}\left(\mathrm{g} \mathrm{cm}^{-3}\right)$ & $0.92-1.83$ & $1.46 \pm 0.20$ & Core method \\
\hline $\mathrm{SOC}\left(\mathrm{g} \mathrm{kg}^{-1}\right)$ & $0.30-30.2$ & $8.11 \pm 6.35$ & Walkley-Black method \\
\hline $\mathrm{pH}$ & $3.5-8.1$ & $6.1 \pm 1.0$ & Legacy data from Soil Survey Report \\
\hline Sand $(\%)$ & $1.67-88.2$ & $38.6 \pm 19.4$ & Legacy data from Soil Survey Report \\
\hline Silt $(\%)$ & $5.37-65.7$ & $37.7 \pm 12.3$ & Legacy data from Soil Survey Report \\
\hline Clay $(\%)$ & $4.6-56.2$ & $23.7 \pm 10.7$ & Legacy data from Soil Survey Report \\
\hline
\end{tabular}

Table 1. Description of soil properties of 230 samples used for developing PTFs in this study

The 230 samples were randomly divided into two parts: the training set contained $80 \%$ of the data (184 samples) and was used to develop the models, and the validation set contained the remaining $20 \%$ of the data (46 samples) and was used to validate the proposed model. In order to determine the relationships between bulk density and soil properties, multiple regression models were developed by the REG procedure with a stepwise variable selection option [45]. Variables in Table 1 were considered for multiple regression modeling because researches have shown significant relationship between these variables and bulk density. $R^{2}$ and root mean square error (RMSE) were used to compare the predictive capacities of proposed regression models.

The proposed models for estimating bulk density of arable soils in Taiwan are shown in Table 2. Model A, which included $\log (\mathrm{d})$ and $[\ln (\mathrm{SOC})]^{2}$, can account $40 \%$ of the variation of bulk density. Adding $\mathrm{pH}$ as a predictor has a minor improvement of predictive quality (44\%) in Model B. Besides, we found that $\mathrm{pH}$ is not available in part of legacy dataset, thus Model A with less parameters was used to predict bulk density. Although soil texture was used to predict bulk density in many studies [33-34,37-38], it is not significantly correlated with bulk density in this study.

\begin{tabular}{|c|c|c|c|c|c|}
\hline Model & Intercept & $\log (d)$ & {$[\operatorname{Ln}(\mathrm{SOC})]^{2}$} & $\mathrm{pH}$ & $\mathbf{R}_{\mathrm{adj}}^{2}$ \\
\hline A & $1.3026^{* * *}$ & $0.169^{* * *}$ & $-0.256^{* * *}$ & -- & 0.40 \\
\hline$B$ & $1.0386^{* * *}$ & $0.1447^{* * *}$ & $0.022^{* * *}$ & $0.0476^{* * *}$ & 0.44 \\
\hline
\end{tabular}

Table 2. Coefficients of candidate PTFs for Bd developed in this study. $\mathrm{d}$ : depth (cm), SOC: soil organic carbon content $\left(\mathrm{g} \mathrm{kg}^{-1}\right) .{ }^{* *} \mathrm{p}<0.001$ 
The proposed model was validated by the validation set (46-horizon samples) and the performance was shown in Figure 1. Results shows that only about $15 \%$ of the variation $\left(\mathrm{R}^{2}=\right.$ 0.15) was explained by the predicted bulk density with a RMSE equivalent to $0.207 \mathrm{~g} \mathrm{~cm}^{-3}$. Due to small available dataset and few variables, the proposed model revealed a very limited predictive potential, however, this model is statistically significant $(p=0.0052)$. To obtain a high accuracy and great precision in estimating soil bulk density, an equation specific for each range of soils of relevance to a particular research program should be used rather than rely on general PTFs [33]. Because bulk density was rarely measured, and no PTF of Taiwan soils has been developed, we adopted this model to estimate the bulk density of arable soil and, thereafter, to evaluate the SOC stock:

$$
\mathrm{Bd}=1.3026+0.169 \log (\mathrm{d})-0.256[\operatorname{Ln}(\mathrm{SOC})]^{2}
$$

where Bd is the soil bulk density $\left(\mathrm{g} \mathrm{cm}^{-3}\right), \mathrm{d}$ is the sample depth $(\mathrm{cm})$, and SOC is the soil organic carbon content $\left(\mathrm{g} \mathrm{kg}^{-1}\right)$.
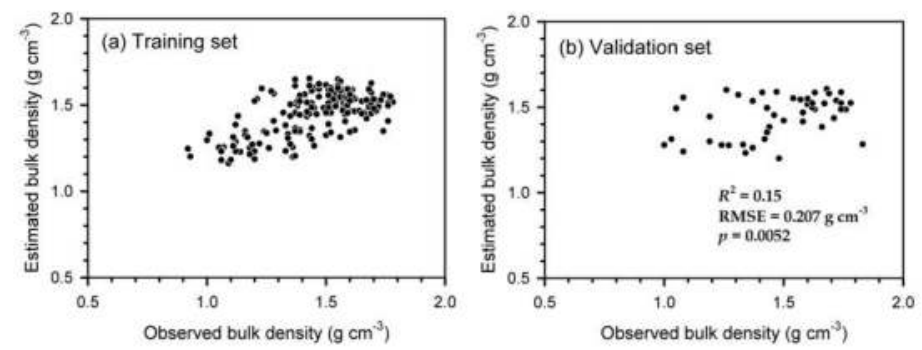

Figure 1. Correlation of observed bulk density and estimated bulk density of (a) training set and (b) validation set.

\subsection{Datasets for estimation of SOC stock in arable soils}

Dataset for estimating the SOC stock in agricultural soils was obtained from a detailed soil survey which was performed by TARI in 2006. In the field, one pedon was sampled by auger within a $250 \mathrm{~m}$ by $250 \mathrm{~m}$ grid, that is, every 6.25 ha of the arable land has a representative soil pedon. Sampling depths were 0 to 15,15 to 30,30 to 60,60 to 90,90 to 120 , and 120 to $150 \mathrm{~cm}$, respectively. We use soil data of three important agricultural counties: Taoyuan, Changhua and Tainan County in the northern, central and southern regions of Taiwan, respectively (Figure 2). After removing the outliers and missing data, the extracted database contains the information of 19,024 soil pedons. Only organic matter (OM, \%) was available soil properties. Therefore, here we converted the OM content to SOC content by dividing a Van Bemmelen factor of 1.724 , on the assumption that SOM contains $58 \%$ of organic C averagely. Soil carbon stock for a given depth is calculated as follows: 
$\operatorname{SOC}$ stock $\left(\mathrm{kg} \mathrm{m}^{-2}\right)=\left[\operatorname{SOC}\left(\mathrm{g} \mathrm{kg}^{-1}\right) \times \mathrm{Bd}\left(\mathrm{g} \mathrm{cm}^{-3}\right) \times\right.$ thickness $\left.(\mathrm{cm})\right] / 100$

where Bd is bulk density which was calculated by using the Eq (1).

Finally, we estimated the SOC stocks at different depths of three counties and used the kriging method of geostatistics and digital soil mapping techniques.

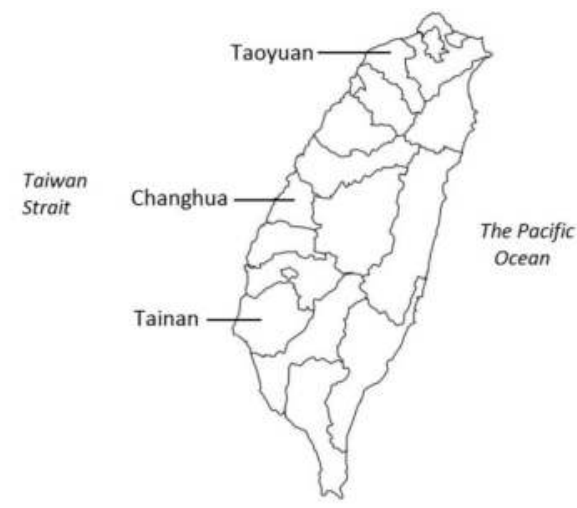

Bashi Channel

Figure 2. The location of Taoyuan, Changhua and Tainan Counties in Taiwan.

\section{Soil C stock in Taoyuan County (red soil)}

\subsection{Background of Taoyuan soils}

The Taoyuan County is located in northwestern Taiwan, about $50 \mathrm{~km}$ southwest of Taipei city. The southeastern part of Taoyuan is mountainous area of high elevation, and the elevation decreases from southeast to northwest into the sea. Except for the mountain area, most of the agricultural lands develop on the terraces which were originally created as an alluvial fan by the paleo-Tahan River. The Tahan River, currently flowing in a northeastern direction, had flowed westwards into the sea before the Taoyuan Terrace formed [46]. Due to tectonic activities, the paleo-Tahan River gradually migrated clockwise and left several terraces behind [47], including Yangmei, Talun, Chungli, and Taoyuan Terraces in the Taoyuan County. Slopes of the terraces are between 1 and 7\%, going down gently from the eastern hill land to the western seashore. The soils were developed on Quaternary alluvial deposits and have a minimum thickness of $5 \mathrm{~m}$ [48]. Cobbles are overlaid by finer alluvial materials in the terrace, and water usually perches at the contact between these two layers. Most of the terraces mentioned above are covered by red soils and gravels. It is generally believed that the red-colored soils in Taiwan could be developed prior to $30 \mathrm{ka}$ [46]. 
Figure 3 shows the climatic data from two meteorological stations which are approaching to Taoyuan. Generally, the mean air temperature is $28.3^{\circ} \mathrm{C}$ in summer and $16.5^{\circ} \mathrm{C}$ in winter. The mean annual rainfall over the past decades (1981-2010) was $2061 \mathrm{~mm}$. The average monthly evapotranspitation peak is July, but never exceeds the average monthly rainfall. The soil temperature and moisture regimes of Taoyuan soils are hyperthermic and udic.
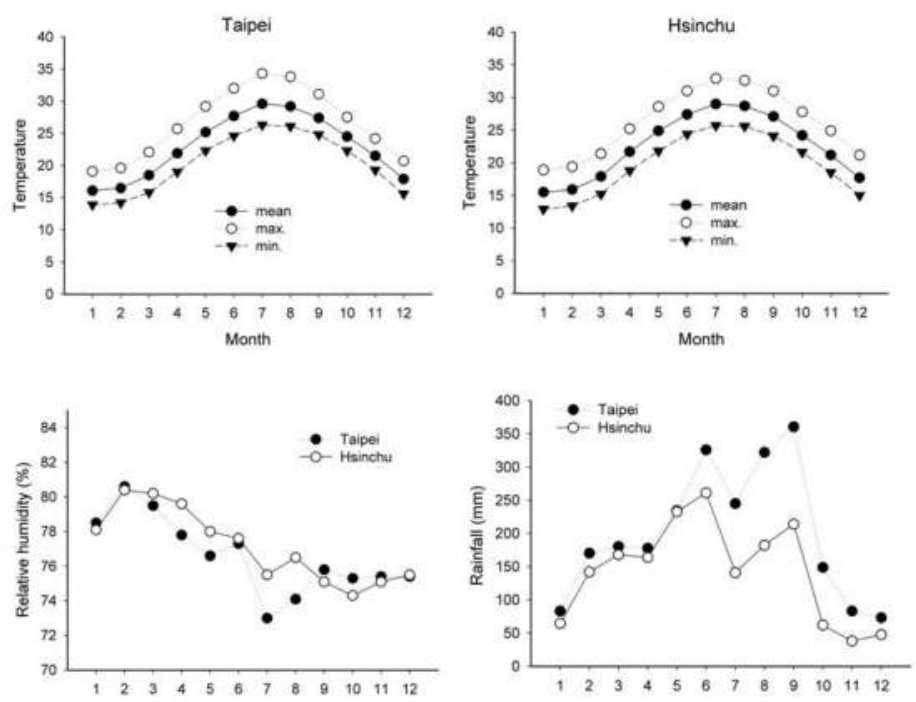

Figure 3. Mean monthly distribution of air temperature, relative humidity and precipitation at Taipei and Hsinchu meteorological stations which are approaching to Taoyuan. Data collected from 1981 to 2010, according to the Central Weather Bureau of Taiwan (http://www.cwb.gov.tw).

\subsection{Land use and soil series of Taoyuan}

Arable lands of Taoyuan County is 37,544 ha, occupying $30.8 \%$ of the total area. About $29 \%$ of the arable land were used for rice production and $18 \%$ of the arable land were used for upland crops production, including vegetables $(10.7 \%)$, tea $(2.4 \%)$, fruit $(1.9 \%)$, grains $(0.3 \%)$ and other crops (2.7\%). About $53 \%$ of the total arable land was fallowed in Taoyuan County. Prior to 1950, the agricultural land in the terrace was used for tea production. After an irrigation system and reservoir were constructed in the 1950s, the terrace soils were used for rice production. Rice was harvested twice per year during the growing season between March and October, and then the soils were fallowed in winter.

A suit of soil profile properties and horizons falling within a particular range are said to belong to the same soil series. According to Soil Taxonomy [49], soil series are specific types of soils named after a geographic feature (town, river, etc.) near where they were first recognized. Based on Soil Survey Report of Taoyuan [43], there are 68 soil series which can be 
grouped into five Soil Orders: Histosol, Oxisol, Inceptisol, Entisol and Ultisol. About 56\%, $32 \%$ and $9 \%$ of the Taoyuan soils belong to Ultisols, Entisols and Inceptisols, respectively. Description of important soil series in Taoyuan are shown in Table 3. Generally, the most arable soils in Taoyuan County are acidic, well drained, and clayed soil texture.

\begin{tabular}{|c|c|c|c|c|c|c|c|}
\hline \multicolumn{2}{|c|}{ Soil series Occupied } & \multirow{2}{*}{$\begin{array}{l}\text { Depth } \\
\text { class }^{\dagger}\end{array}$} & \multirow[t]{2}{*}{ Soil texture ${ }^{\ddagger}$} & \multirow{2}{*}{\multicolumn{2}{|c|}{ Drainage $\mathrm{pH}^{\pi} \mathrm{H}$}} & \multirow[t]{2}{*}{$\mathrm{SMR}^{\S}$} & \multirow{2}{*}{$\begin{array}{l}\text { Subgroup of } \\
\text { Soil Taxonomy (USDA) }\end{array}$} \\
\hline code & Area (\%) & & & & & & \\
\hline Pc & 15.6 & VD & $\mathrm{SiC}$ & ED & $<5$ & Udic & Typic Kandiudox \\
\hline Sk & 9.9 & VS & $\mathrm{SL}$ & W & $<5$ & Udic & Lithic Udipsamment \\
\hline $\mathrm{Lt}$ & 6.4 & VD & $\mathrm{SiCL}$ & W & $5.0-7.0$ & Udic & Oxyaquic Paleudult \\
\hline Tw & 5.8 & VD & $\mathrm{SiCL}$ & W & $<5$ & Udic & Plinthic Paleudult \\
\hline $\mathrm{Hh}$ & 5.1 & VD & $\mathrm{SiC}$ & $P$ & $5.0-7.0$ & Aquic & Typic Plinthaqult \\
\hline Tc & 4.2 & $\mathrm{D}$ & $\mathrm{CL}$ & W & $<5$ & Udic & Typic Paleudult \\
\hline $\mathrm{Pu}$ & 4.2 & VD & $\mathrm{SiCL}$ & MW & $5.0-7.0$ & Udic & Typic Plinthudult \\
\hline $\mathrm{Hk}$ & 4.0 & $\mathrm{D}$ & $\mathrm{SiC}$ & W & $5.0-7.0$ & Udic & Plinthic Paleudult \\
\hline $\mathrm{Tl}$ & 3.7 & VD & $\mathrm{CL}$ & W & $5.0-7.0$ & Udic & Typic Paleudult \\
\hline Lk & 2.2 & VD & $\mathrm{SiC}$ & W & $5.0-7.0$ & Udic & Plinthic Paleudult \\
\hline $\mathrm{Nc}$ & 2.2 & $D$ & $\mathrm{~L}$ & SP & $5.0-7.0$ & Udic & Typic Udipsamment \\
\hline LC & 2.0 & VD & $\mathrm{SiCL}$ & SP & $<5$ & Udic & Plinthaquic Paleudult \\
\hline Total & 65.1 & & & & & & \\
\hline
\end{tabular}

Table 3. Important soil series of Taoyuan County in Taiwan. ${ }^{\dagger}$ Depth class: VS, very shallow $(<25 \mathrm{~cm})$; $\mathrm{S}$, shallow (25-50

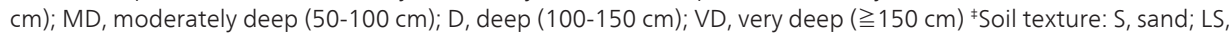
loamy sand; SL, sandy loam; L, loam; SiL, silty loam; Si, silt; SCL, sandy clay loam; CL, clay loam; SiCL, silty clay loam; SC, sandy clay; SiC, silty clay; C, clay. Drainage: ED, excessively drained; W, well drained; MW, moderately well drained; SP, somewhat poorly drained; $\mathrm{P}$, poorly drained; VP, very poorly drained. ${ }^{\S} \mathrm{SMR}$ : soil moisture regime.

\subsection{Estimation of SOC stock and digital soil mapping}

Estimation of SOC stocks at different depths of Taoyuan County is shown in Table 4. Available datasets of Taoyuan County are composed of 4,872 pedons. The mean SOC stock at depths of $0-15 \mathrm{~cm}$ and $15-30 \mathrm{~cm}$ is $3.77 \pm 1.29 \mathrm{~kg} \mathrm{~m}^{-2}$ and $3.04 \pm 1.14 \mathrm{~kg} \mathrm{~m}^{-2}$, respectively, and SOC stock decreases with increasing soil depth. The mean SOC stock of arable soils of Taoyuan is $8.17 \pm 4.99 \mathrm{~kg} \mathrm{~m}^{-2}$ from surface to $150 \mathrm{~cm}$. It indicates that the red soils of Taoyuan is less soil fertility, and the SOC stock is less than the mean value $\left(11 \mathrm{~kg} \mathrm{~m}^{-2}\right)$ of all arable soils of Taiwan $[29,50]$. On average, $83 \%$ of the total SOC stock in the upper $150 \mathrm{~cm}$ is stocked in the surface $30 \mathrm{~cm}$. It implies the potentially large amounts of $\mathrm{CO}_{2}$ may be released by changes in land use. 


\begin{tabular}{cllllll}
\hline Soil depth & Soil sample & \multicolumn{2}{l}{ SOC stock $\left(\mathbf{k g ~ m}^{-2}\right)$} & & \\
\hline$(\mathrm{cm})$ & number & Mean \pm SD & Median & Skewness & Kurtosis & Data range \\
\hline $0-15$ & 4872 & $3.77 \pm 1.29$ & 3.77 & 0.07 & -0.42 & $0.45-8.07$ \\
\hline $15-30$ & 2751 & $3.04 \pm 1.14$ & 2.98 & 0.25 & -0.51 & $0.55-6.33$ \\
\hline $30-60$ & 1735 & $4.73 \pm 2.09$ & 4.49 & 0.36 & -0.77 & $0.77-9.98$ \\
\hline $60-90$ & 843 & $3.20 \pm 1.31$ & 3.08 & 0.60 & -0.29 & $0.81-7.08$ \\
\hline $90-120$ & 552 & $2.71 \pm 0.97$ & 2.65 & 0.30 & -0.86 & $0.37-4.90$ \\
\hline $120-150$ & 258 & $2.52 \pm 0.91$ & 2.42 & 0.54 & 0 & $0.43-4.89$ \\
\hline $0-150$ & 4872 & $8.17 \pm 4.99$ & 6.31 & 0.78 & -0.57 & $0.65-19.99$ \\
\hline
\end{tabular}

Table 4. Estimation of SOC stock at different depths from dataset of Taoyuan County
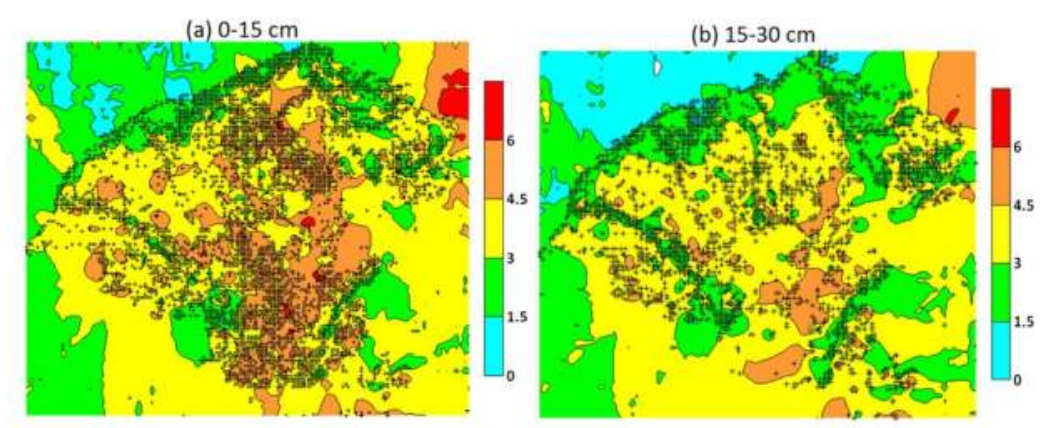

(c) $30-60 \mathrm{~cm}$

(d) $60-90 \mathrm{~cm}$
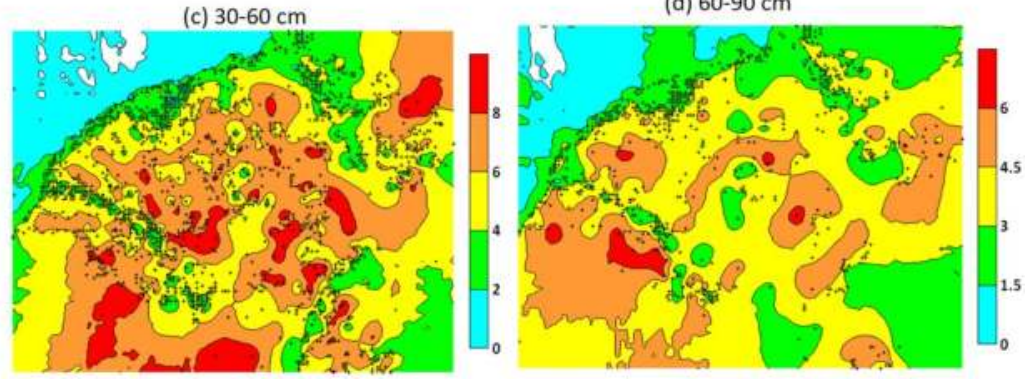

Figure 4. Digital soil mapping of the estimated SOC stock (unit: $\mathrm{kg} \mathrm{m}^{-2}$ ) at different depths in arable soils of Taoyuan County. Cross symbols represent the soil sampling pedons. Each pedon was sampled by auger within a $250 \mathrm{~m}$ by 250 m grid (6.25 ha). 
(e) $90-120 \mathrm{~cm}$
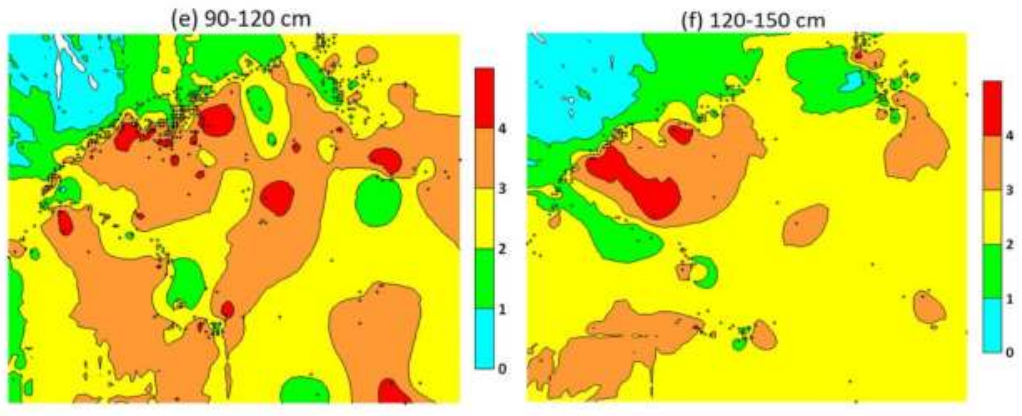

(g) $0-150 \mathrm{~cm}$

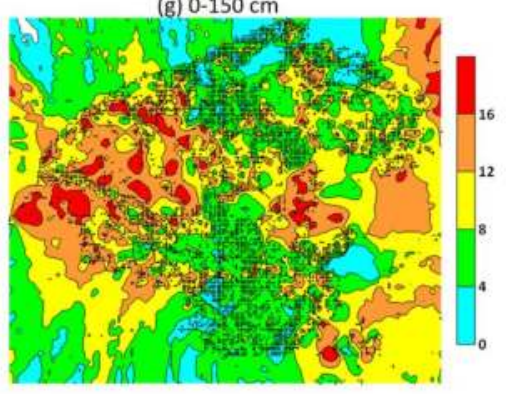

Figure 4. Digital soil mapping of the estimated SOC stock (unit: $\mathrm{kg} \mathrm{m}^{-2}$ ) at different depths in arable soils of Taoyuan County. Cross symbols represent the soil sampling pedons. Each pedon was sampled by auger within a $250 \mathrm{~m}$ by 250 m grid (6.25 ha).

Figure 4 shows the digital soil mapping of SOC stock in arable soils of Taoyuan County. Generally, soils in the western parts of Taoyuan have larger SOC in the depth 0-150 cm. In Taoyuan, the rice growing soils are largest in the western parts where Hsinwu and Yangmei are located. Therefore, we suggested that the paddy soils which growing rice can continuously accumulate organic carbon into the soils due to the addition of rice residues and more anaerobic condition during flooding cultivation. On the other hand, the increasing fallow lands with more aerobic condition and without addition of rice residues probably result in the decreases of SOC stock in Taoyuan County.

\section{Soil C stock in Changhua County (slate alluvial soils)}

\subsection{Background of Changhua soils}

Changhua County is located in the central Taiwan (Figure 2) and between the Dadu River and the Choushui River, the latter one is the longest river in Taiwan. Hence, there are two sources of soil parent materials in Changhua County, strata under the north part of soils are composed of sandstone and shale deposits from Daua River, while most soils in Changhua County are developed from limestone and slate clay deposited by the Choushui River and 
its distributaries. Differences in parent materials have great influences on the soil properties of the Changhua County. The elevation decreases gently from the eastern Pakua terrace to the western coastal plain.
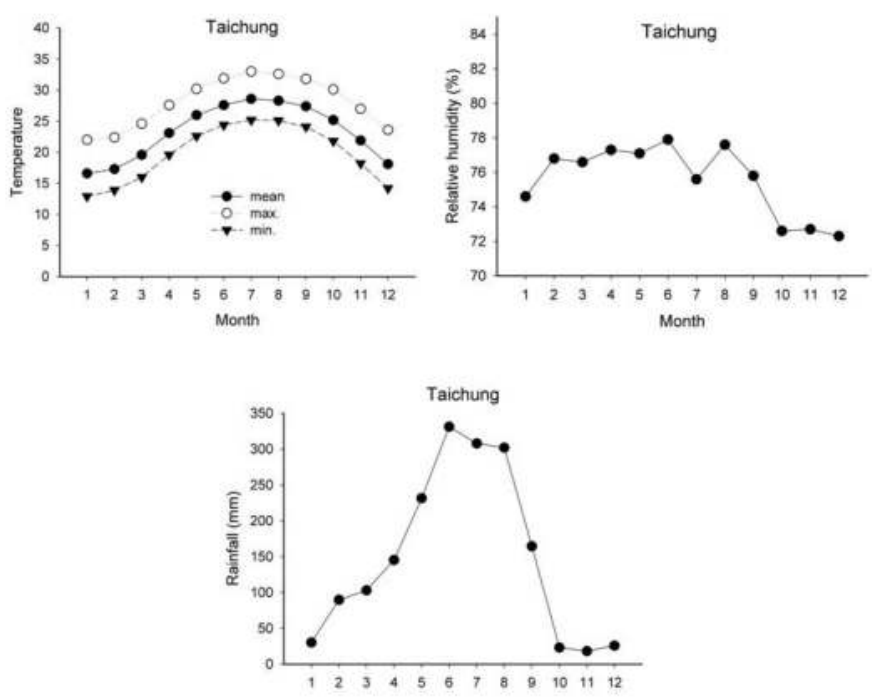

Figure 5. Mean monthly distribution of temperature, relative humidity and precipitation at Taichung meteorological stations which is approaching to Changhua. Data recorded from 1981 to 2010, according to the Central Weather Bureau of Taiwan (http://www.cwb.gov.tw).

Figure 5 shows the climatic data from the Taichung meteorological station which is approaching to Changhua County. The mean air temperature is $28.0^{\circ} \mathrm{C}$ in summer and $17.3^{\circ} \mathrm{C}$ in winter. The mean annual rainfall over the past decades (1981-2010) is $1773 \mathrm{~mm}$, and the monthly rainfall is relatively low between October and February. The soil temperature and moisture regimes of the study area are hyperthermic and udic, respectively.

\subsection{Land use and soil series of Changhua}

Arable lands of Changhua is 63,722 ha, occupying $59 \%$ of the total area. About $43 \%$ of the arable land grows rice, and rice production of Changhua is the highest county in Taiwan. About $50 \%$ of the arableland grows crops, including vegetables $(21 \%)$, fruits $(11 \%)$, grains $(8.5 \%)$ and flowers (7.3\%). About $7.6 \%$ of the total arable land was fallowed in Changhua County. Because of the warm and humid climate, high soil fertility, complete irrigation system and accessibility, most area of the plain are used for croplands. Rice is harvested twice during the growing season, and the agricultural land use of Changhua is most intensive in Taiwan. 


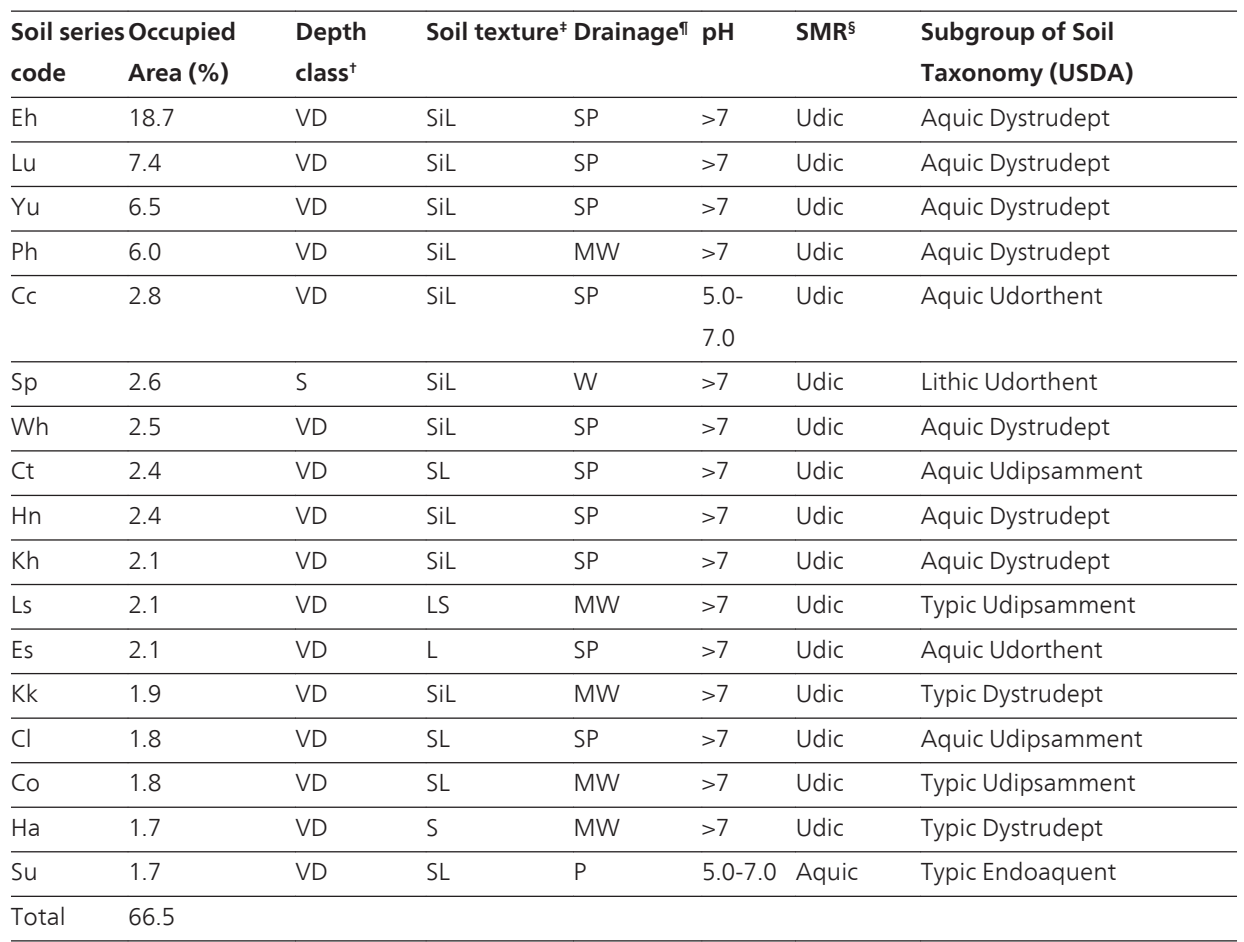

Table 5. Important soil series in Changhua County ${ }^{\dagger}$ Depth class: VS, very shallow $(<25 \mathrm{~cm})$; S, shallow $(25-50 \mathrm{~cm}) ; \mathrm{MD}$, moderately deep (50-100 cm); D, deep (100-150 cm); VD, very deep ( $\geqq 150 \mathrm{~cm}$ ) `Soil texture: S, sand; LS, loamy sand; SL, sandy loam; L, loam; SiL, silty loam; Si, silt; SCL, sandy clay loam; CL, clay loam; SiCL, silty clay loam; SC, sandy clay; SiC, silty clay; C, clay. Drainage: ED, excessively drained; W, well drained; MW, moderately well drained; SP, somewhat poorly drained; P, poorly drained; VP, very poorly drained. §SMR: soil moisture regime.

Based on Soil Survey Report of Changhua [51], there are 65 soil series which can be grouped into two Soil Orders: Inceptisol and Entisol. 65\% of the Changhua soils belong to Inceptisols, while the other $35 \%$ of soils belong to Entisols. Description of important soil series in Changhua are shown in Table 5. In general, Changhua soils are calcareous, silty-loam textured, and somewhat poorly drained.

\subsection{Estimation of SOC stock and digital soil mapping}

Available datasets of Changhua are composed of 6,749 soil pedons, and the estimation of SOC stocks at different depths is shown in Table 6. The mean SOC stock at depths of 0-15 $\mathrm{cm}$ and $15-30 \mathrm{~cm}$ is $2.34 \pm 0.90 \mathrm{~kg} \mathrm{~m}^{-2}$ and $1.84 \pm 0.68 \mathrm{~kg} \mathrm{~m}^{-2}$, respectively. The mean SOC stock of arable soils of Changhua is $9.49 \pm 5.12 \mathrm{~kg} \mathrm{~m}^{-2}$ from surface to $150 \mathrm{~cm}$. On average, $44 \%$ of the total SOC stock of $150 \mathrm{~cm}$ is stocked in the surface $30 \mathrm{~cm}$, implying the changes in land use have potentially impacts on $\mathrm{CO}_{2}$ release. 


\begin{tabular}{cllllll}
\hline Soil depth & Soil sample & \multicolumn{2}{l}{ SOC stock $\left(\mathbf{k g ~ m}^{-2}\right)$} & & & \\
\hline (cm) & number & $\begin{array}{l}\text { Mean } \pm \text { Standard } \\
\text { deviation }\end{array}$ & Median & Skewness & Kurtosis & Data range \\
\hline $0-15$ & 6749 & $2.34 \pm 0.90$ & 2.24 & 0.54 & -0.05 & $0.40-6.25$ \\
\hline $15-30$ & 5757 & $1.84 \pm 0.68$ & 1.81 & 0.39 & 0 & $0.46-5.84$ \\
\hline $30-60$ & 5132 & $2.97 \pm 1.11$ & 2.86 & 0.48 & 0 & $0.82-9.19$ \\
\hline $60-90$ & 4333 & $2.63 \pm 1.01$ & 2.50 & 0.63 & 0.60 & $0.81-8.64$ \\
\hline $90-120$ & 3516 & $2.43 \pm 0.98$ & 2.26 & 0.85 & 0.92 & $0.80-7.56$ \\
\hline $120-150$ & 1093 & $2.31 \pm 0.97$ & 2.15 & 1.26 & 2.97 & $0.81-7.82$ \\
\hline $0-150$ & 6749 & $9.49 \pm 5.12$ & 9.12 & 0.51 & 0.62 & $0.47-41.8$ \\
\hline
\end{tabular}

Table 6. Estimation of SOC stock at different depths from dataset of Changhua County

Figure 6 shows the digital soil mapping of SOC stock in arable soils of Changhua. Soils with larger $C$ stocks are located at the high productivity area, including (1) Chutang and Pitou in the southern region, (2) Yungchih and Sheto in the southeastern region, and (3) Hsiushui, Homei and Shenkang in the north region of Changhua. Soils with extremely high SOC content (> $30 \mathrm{~kg} \mathrm{~m}^{-2}$ at $150 \mathrm{~cm}$ depth) in the north part of Changhua are belong to Histosols.
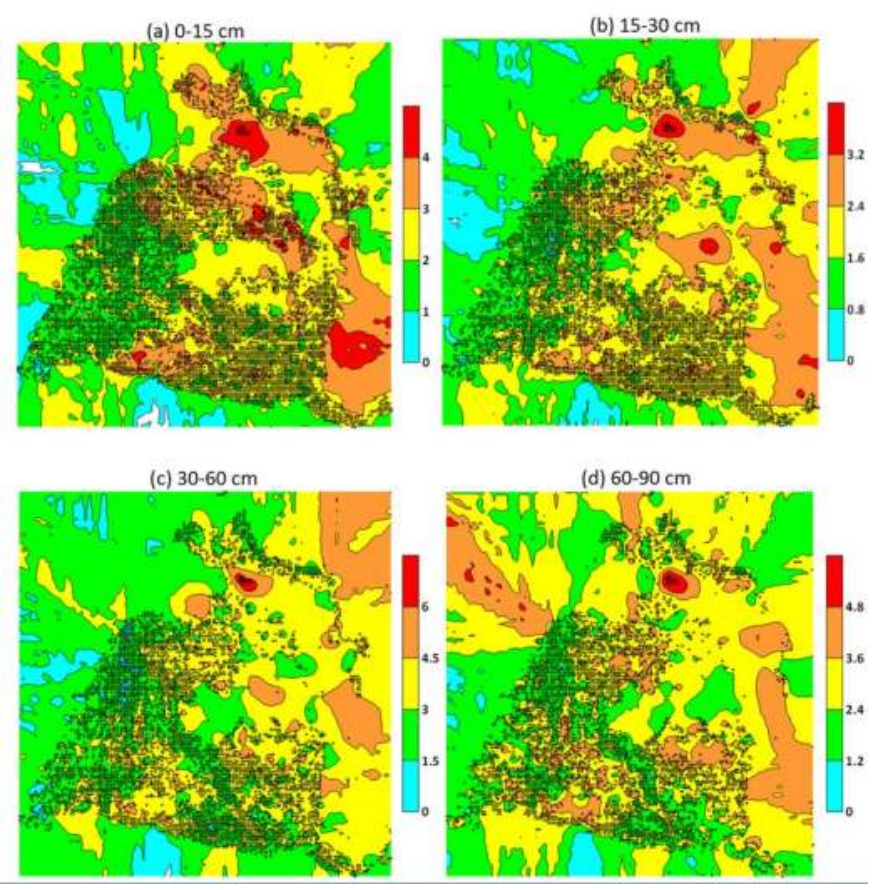

Figure 6. Digital soil mapping of the estimated SOC stock at different depth in arable soils of Changhua (unit: $\left.\mathrm{kg} \mathrm{m}^{-2}\right)$. Cross symbols represent the soil sampling pedons. Each pedon was sampled by auger within a $250 \mathrm{~m}$ by $250 \mathrm{~m}$ grid ( $6.25 \mathrm{ha}$ ). 

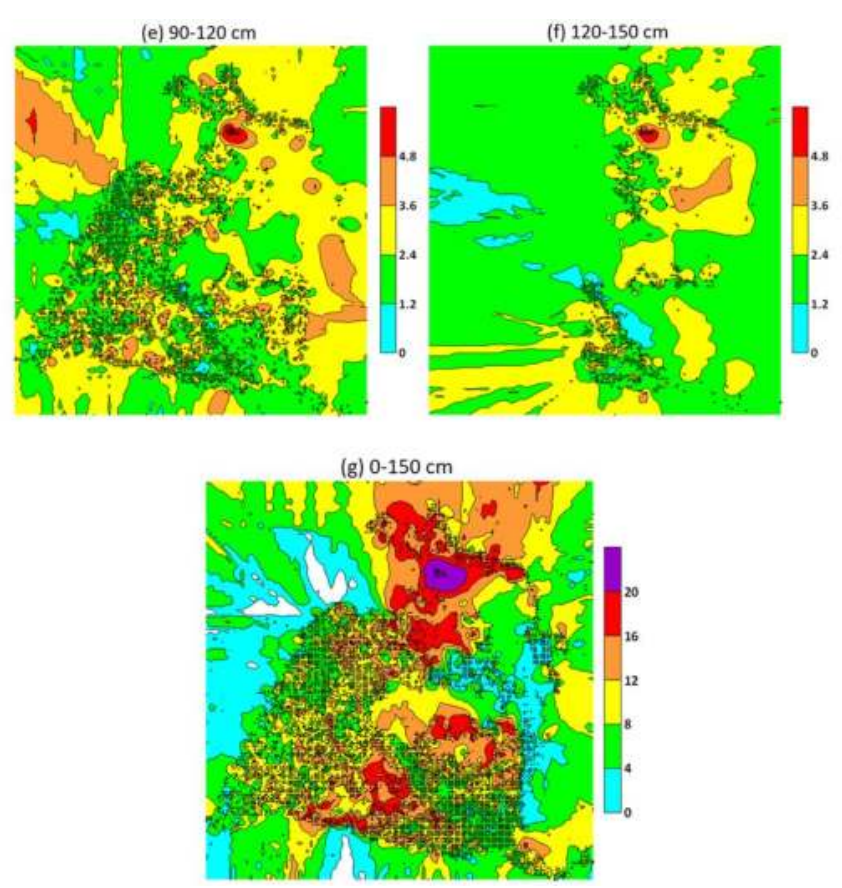

Figure 6. Digital soil mapping of the estimated SOC stock at different depth in arable soils of Changhua (unit: $\left.\mathrm{kg} \mathrm{m}^{-2}\right)$. Cross symbols represent the soil sampling pedons. Each pedon was sampled by auger within a $250 \mathrm{~m}$ by $250 \mathrm{~m}$ grid ( $6.25 \mathrm{ha}$ ).

\section{Soil C stock in Tainan County (sandstone and shale alluvial soils)}

\subsection{Background of Tainan soils}

Tainan County is located in the southwestern Taiwan(Figure2). About one third area is occupied by hill land (30-50 m asl) in the eastern part of Tainan County, and the other two third area is alluvial plain. In general, Tainan County is situated in the central part of Chia-Nan Plain, which is the largest plain with high agricultural production of Taiwan. Most soils of Tainan are developed from sandstone, shale and mudstone deposits of the Zengwun River and the Bajhang River from the eastern hill regions.

Figure 7 shows the climatic data from the Tainan meteorological station. Tainan County is located in south of the Tropic Cancer, thus, the temperature is relatively high. The mean air temperature is $28.7^{\circ} \mathrm{C}$ in summer and $18.4^{\circ} \mathrm{C}$ in winter. The mean annual rainfall over the past decade (1981-2010) is $1698 \mathrm{~mm}$. Except for the raining season beginning from May to September, the monthly rainfall is less than the evapotranspiration. The soil temperature regime of the study area is hyperthermic, and soil moisture regime of most area is ustic. 

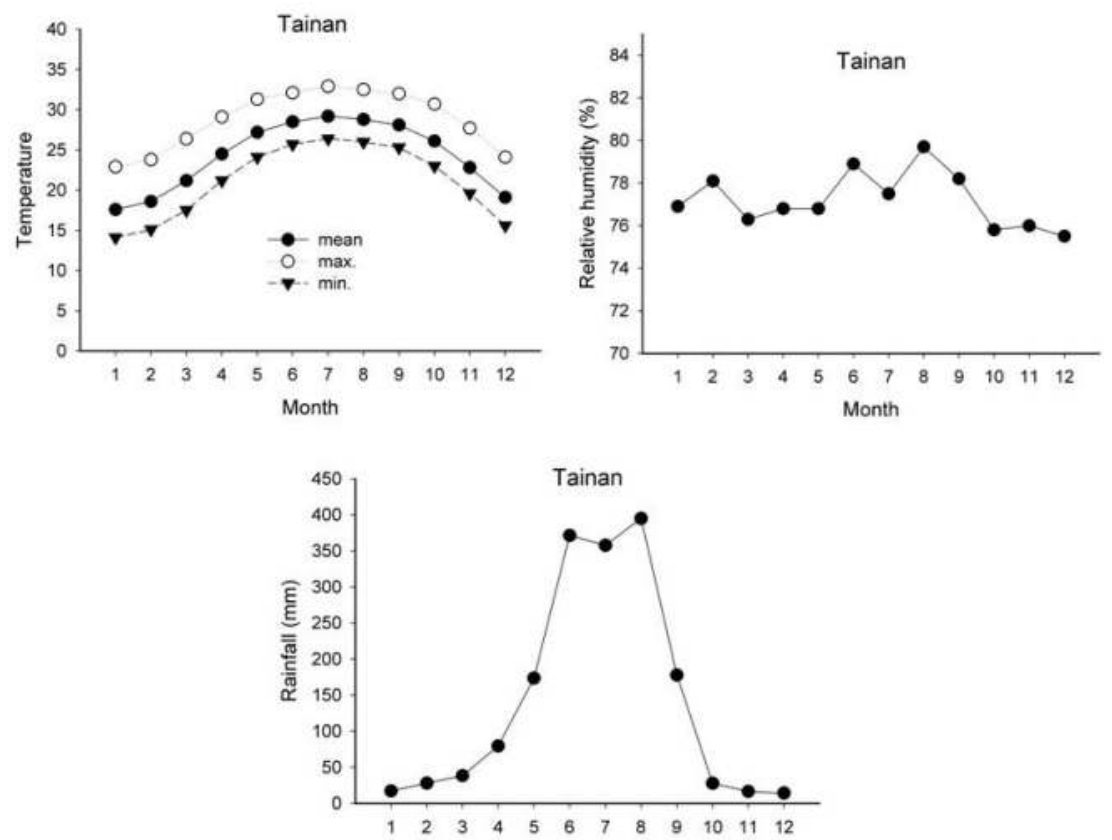

Figure 7. Mean monthly distribution of temperature, relative humidity and precipitation at Tainan meteorological stations. Data recorded from 1981 to 2010, according to the Central Weather Bureau of Taiwan (http:// www.cwb.gov.tw).

\subsection{Land use and soil series of Tainan}

Arable lands of Tainan is 91,974 ha, occupying $45.6 \%$ of the total area. About $30 \%$ and $25 \%$ of the arable land grows fruits and rice, respectively, and $28 \%$ of the arable land grows crops vegetables (18\%), grains $(5.7 \%)$, sugarcanes $(2.2 \%)$ and other crops. About $17 \%$ of the total arable land was fallowed in Tainan County. Due to the rainfall is often less than the evapotranspiration, especially when southwestern monsoon occurs during the winter, deficiency of soil water content is the limit factor of crop growing. Strong evaporation and the irrigation from groundwater result in saline soils in the coastal region of Tainan County.

Based on Soil Survey Report of Tainan [44], there are 68 soil series which can be grouped into three Soil Orders: Alfisol, Inceptisol and Entisol. About $57 \%$ of the Tainan soils belong to Entisols and $34 \%$ of soils belong to Inceptisols. Description of important soil series in Tainan are shown in Table 7. Most Tainan soils are sandy loam to silt loam soil texture, neutral to basic reaction and well drained soils. 


\begin{tabular}{|c|c|c|c|c|c|c|c|}
\hline \multicolumn{3}{|c|}{ Soil series Occupied Area Depth } & \multirow[t]{2}{*}{ Soil texture ${ }^{\ddagger}$} & \multirow{2}{*}{\multicolumn{2}{|c|}{ Drainage ${ }^{\pi} \mathrm{pH}$}} & \multirow[t]{2}{*}{ SMR $^{\S}$} & \multirow{2}{*}{$\begin{array}{l}\text { Subgroup of Soil } \\
\text { Taxonomy (USDA) }\end{array}$} \\
\hline code & $(\%)$ & class $^{\dagger}$ & & & & & \\
\hline$\overline{C f}$ & 16.1 & VD & SL & MW & $>7$ & Ustic & Typic Ustifluvent \\
\hline$\overline{A n}$ & 9.1 & VD & SiL & MW & $>7$ & Ustic & Typic Dystrustept \\
\hline$\overline{T s}$ & 7.4 & VD & SiL & W & $>7$ & Ustic & Typic Dystrustept \\
\hline $\mathrm{Hk}$ & 6.4 & VD & SL & MW & $>7$ & Ustic & Typic Ustipsamment \\
\hline Ly & 4.7 & VD & SiL & W & $>7$ & Ustic & Typic Ustifluvent \\
\hline Je & 4.2 & VD & L & W & $>7$ & Ustic & Typic Dystrustept \\
\hline Lh & 3.5 & VD & $\mathrm{SiCL}$ & W & $>7$ & Ustic & Typic Paleustalf \\
\hline $\mathrm{Tn}$ & 3.3 & VD & $\mathrm{L}$ & W & $5.0-7.0$ & Udic & Typic Dystrudept \\
\hline Sh & 3.2 & VD & LS & W & $5.0-7.0$ & Udic & Typic Udipsamment \\
\hline $\mathrm{Kn}$ & 2.8 & VD & SiL & W & $5.0-7.0$ & Udic & Typic Dystrudept \\
\hline Sk & 2.6 & VD & $\mathrm{SiC}$ & W & $>7$ & Ustic & Typic Dystrustept \\
\hline$\overline{\mathrm{Ku}}$ & 2.0 & VD & SiL & MW & $>7$ & Ustic & Typic Paleustalf \\
\hline Total & 65.2 & & & & & & \\
\hline
\end{tabular}

Table 7. Important soil series in Tainan County ${ }^{\dagger}$ Depth class: VS, very shallow $(<25 \mathrm{~cm})$; S, shallow $(25-50 \mathrm{~cm})$; MD, moderately deep (50-100 cm); D, deep (100-150 cm); VD, very deep ( $\geqq 150 \mathrm{~cm}$ ) ^Soil texture: S, sand; LS, loamy sand; SL, sandy loam; L, loam; SiL, silty loam; Si, silt; SCL, sandy clay loam; CL, clay loam; SiCL, silty clay loam; SC, sandy clay; SiC, silty clay; C, clay. Drainage: ED, excessively drained; W, well drained; MW, moderately well drained; SP, somewhat poorly drained; P, poorly drained; VP, very poorly drained. ${ }^{\S} \mathrm{SMR}$ : soil moisture regime.

\subsection{Estimation of SOC stock and digital soil mapping}

Estimation of SOC stocks at different depths is shown in Table 8. Available datasets of Tainan are composed of 7,403 pedons. The mean SOC stock at depths of $0-15 \mathrm{~cm}$ and $15-30 \mathrm{~cm}$ is $2.05 \pm 0.61 \mathrm{~kg} \mathrm{~m}^{-2}$ and $1.82 \pm 0.50 \mathrm{~kg} \mathrm{~m}^{-2}$, respectively. The mean SOC stock of arable soils of Tainan is $12.4 \pm 5.49 \mathrm{~kg} \mathrm{~m}^{-2}$ in the upper $150 \mathrm{~cm}$. In comparison with Taoyuan and Changhua soils, the total SOC stock in the upper $150 \mathrm{~cm}$ is higher in Tainan. On average, $31 \%$ of the total SOC stock in the upper $150 \mathrm{~cm}$ is stocked in the surface $30 \mathrm{~cm}$.

\begin{tabular}{cllllll}
\hline Soil depth & \multicolumn{2}{l}{ Soil sample } & SOC stock $\left(\mathbf{k g ~ m}^{-2}\right)$ & & \\
\hline$(\mathrm{cm})$ & number & Mean \pm SD & Median & Skewness & Kurtosis & Data range \\
\hline $0-15$ & 7403 & $2.05 \pm 0.61$ & 2.03 & 0.20 & -0.32 & $0.38-3.89$ \\
\hline $15-30$ & 6259 & $1.82 \pm 0.50$ & 1.80 & 0.20 & -0.39 & $0.35-3.19$ \\
\hline $30-60$ & 6152 & $3.12 \pm 0.90$ & 3.05 & 0.34 & -0.13 & $0.27-5.78$ \\
\hline $60-90$ & 5880 & $2.91 \pm 0.87$ & 2.86 & 0.29 & -0.28 & $0.14-5.45$ \\
\hline $90-120$ & 5635 & $2.81 \pm 0.86$ & 2.75 & 0.30 & -0.36 & $0.71-5.26$ \\
\hline $120-150$ & 4711 & $2.74 \pm 0.88$ & 2.68 & 0.28 & -0.53 & $0.61-4.99$ \\
\hline $0-150$ & 7403 & $12.38 \pm 5.49$ & 13.82 & -0.78 & -0.54 & $0.49-20.00$
\end{tabular}

Table 8. Estimation of SOC stock at different depths from dataset of Tainan County 
Fig 8 shows the digital soil mapping of SOC stock in arable soils of Tainan. Generally, the arable lands of Tainan can be divided into eastern and western parts. In the eastern hill regions of Tainan, most soils are used for growing fruits and the SOC stocks are lower than those of the western plains. In the western plains, most soils used for growing rice and crops have larger soil organic carbon pool. Some arable lands are used to grow sugarcane in the western Tainan, and our estimation indicated that the recycling of sugarcane residues may increase the SOC stock in the soil profile.

(a) $0-15 \mathrm{~cm}$

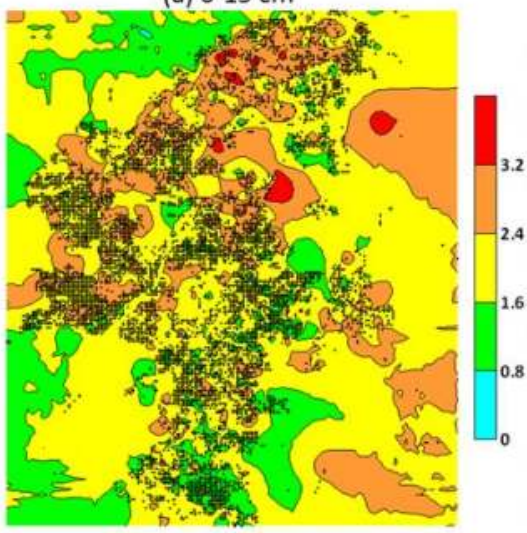

(c) $30-60 \mathrm{~cm}$

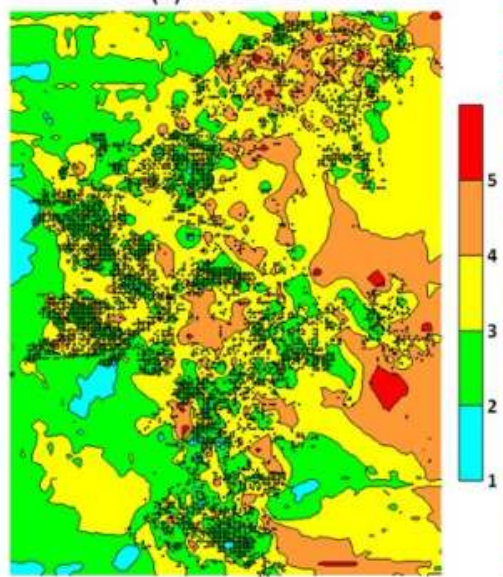

(b) $15-30 \mathrm{~cm}$

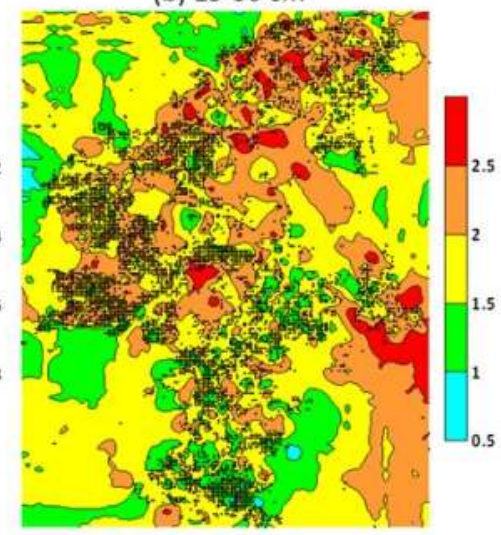

(d) $60-90 \mathrm{~cm}$

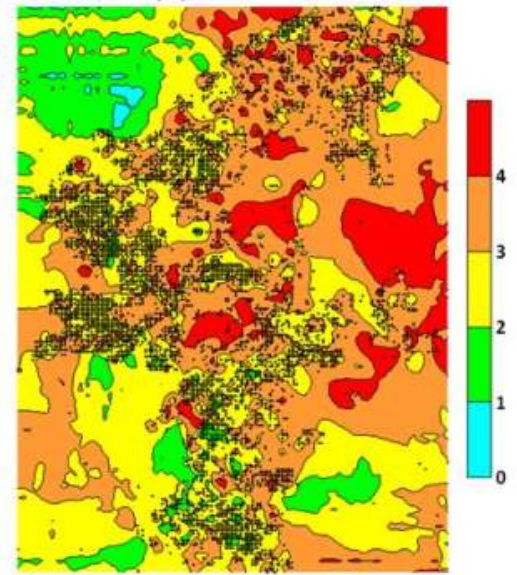

Figure 8. Digital soil mapping of the estimated SOC stock at different depth in arable soils of Tainan (unit: $\mathrm{kg} \mathrm{m}^{-2}$ ). Cross symbols represent the soil sampling pedons. Each pedon was sampled by auger within a $250 \mathrm{~m}$ by $250 \mathrm{~m}$ grid (6.25 ha). 
(e) $90-120 \mathrm{~cm}$

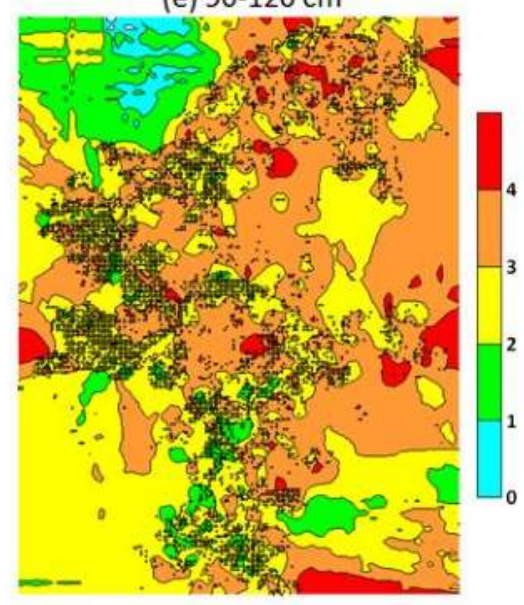

(f) $120-150 \mathrm{~cm}$

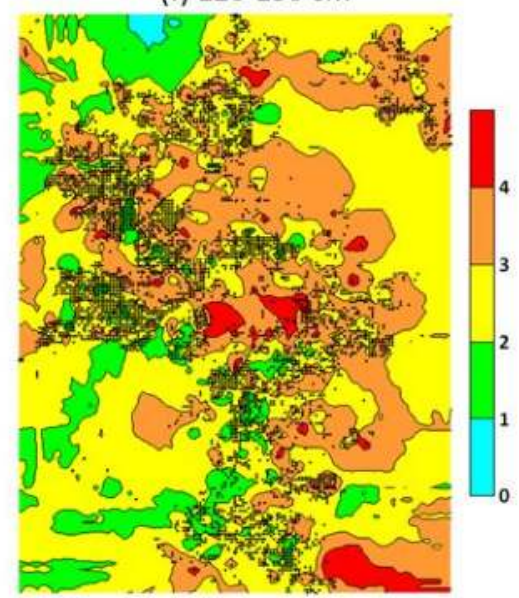

(g) $0-150 \mathrm{~cm}$

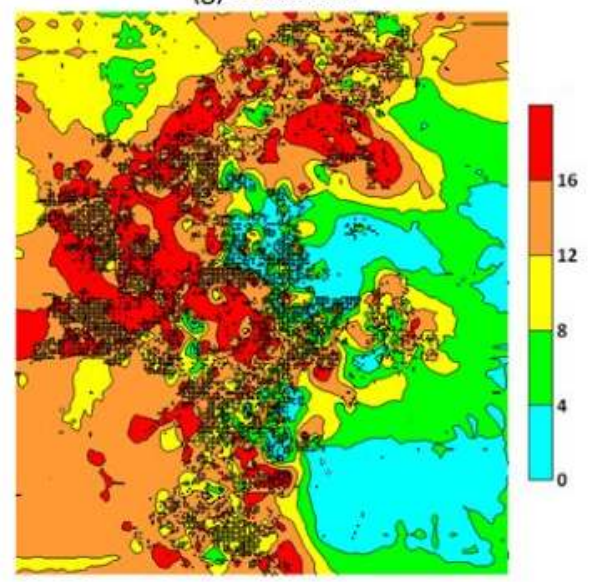

Figure 8. Digital soil mapping of the estimated SOC stock at different depth in arable soils of Tainan (unit: $\mathrm{kg} \mathrm{m}^{-2}$ ). Cross symbols represent the soil sampling pedons. Each pedon was sampled by auger within a $250 \mathrm{~m}$ by $250 \mathrm{~m}$ grid (6.25 ha).

\section{Discussion on SOC stock in arable soils of Taiwan}

In the current study, the mean SOC stock in the upper $150 \mathrm{~cm}$ of arable soils was highest in Tainan County $\left(12.4 \pm 5.49 \mathrm{~kg} \mathrm{~m}^{-2}\right)$, intermediate in Changhua County $\left(9.49 \pm 5.12 \mathrm{~kg} \mathrm{~m}^{-2}\right)$, and lowest in Taoyuan County $\left(8.17 \pm 4.99 \mathrm{~kg} \mathrm{~m}^{-2}\right)$. Our estimation of SOC stocks was close to those 
of warm and humid Asian countries, such as Indonesia $\left(1.21 \mathrm{~kg} \mathrm{~m}^{-2}\right.$ in $0-10 \mathrm{~cm}$ topsoil of Java) [24] and the Philippines (7.16-10.9 $\mathrm{kg} \mathrm{m}^{-2}$ in 0-80 $\mathrm{cm}$ soils)[30], and was also close to those in semi-arid New Mexico (3.35-3.77 $\mathrm{kg} \mathrm{m}^{-2}$ in 0-30 $\mathrm{cm}$ and 7.68-12.1 $\mathrm{kg} \mathrm{m}^{-2}$ in 0-100 $\mathrm{cm}$ soils) [52]. Mean SOC stocks in the arable soils of Taiwan were lower than those of United Kingdom, Australia and South Africa [53-55], which indicating that the differences in SOC stocks at continental scale may be primarily driven by climate condition [24]. Climate data revealed that the rainfall and air temperature is slightly different among three counties: Taoyuan County has a longer rainy season (Figure 3) while Tainan County has distinctive dry season and rainy season (Figure 7), and Changhua County has a relatively moderate rainy season (Figure 5). Because the depletion of the SOC stocks in cultivated soils is caused by oxidation and mineralization, leaching and erosion [5], it is therefore probable that the consistency and periodicity of rainfall (i.e. effective rainfall) is a more significant factor to affect the quantity of soil carbon accumulation than that of simple value of total annual rainfall [54]. In Taoyuan County, stronger leaching and well-drained condition contributed to the weathering and soil development, and the Ultisols covered over 50\% of the arable land of Taoyuan County (Table 3). In Changhua and Tainan Counties, most of the arable soils were classified as Inceptisols and Entisols (Tables 5\& 7), which were reported to have larger SOC stocks than those for Ultisols distributed in Taoyuan County [2,16,28-29,50]. Therefore, we suggested that major soil types are also related to the SOC stock of arable soils in this study.

Based on the digital soil mapping (Figure 4,6,8), spatial variation of SOC stock in topsoil was not always parallel to those in 0-150 cm depth of soils, due to major carbon dynamics on topsoil and in subsoil may be controlled by different regulatory mechanisms $[9,56]$. For example, land use had strong influence on SOC dynamics in topsoil [54], and the correlation between SOC and soil properties (clay content) was highest in soil deeper interval of the profile [9]. There are many factors and processes that determine the direction and rate of change in SOC content when the vegetation types and soil management practices are changed [17]. The nature and amounts of crop residues can influence the direction and amounts of trends in soil C stocks after the crops are harvested [26]. In this case study, for example, long-term planting and the recovery of sugarcane residues may increase the SOC stock in the western parts of Tainan County (Figure 8). Studies in Java [24] and Philippines [25] indicated that the continuous ricegrowing system increased the SOC stocks. Here we have no sufficient SOC data to demonstrate the impact of different crops or land uses changes on arable soils in Taiwan. However, the previous study [29] reported that crop rotation system and fertilizer addition do increase the topsoil SOC content in some counties from 1950 to 1994. Moreover, land use changes from rice-growing soils to fallow or upland cultivation decreased the SOC stock in the upper $30 \mathrm{~cm}$ from 1969 to 2002 in Tainan County [29].

Depletion of SOC stock from the root zone has adversely affected the soil productivity and and environmental quality. On the other hand, increasing the SOC stock will increases the crop yield, especially in the soils where it has been depleted for long term. An increase of 1 ton of SOC can increase the wheat grain yield by $27 \mathrm{~kg} \mathrm{ha}^{-1}$ in North Dakota, USA, and $40 \mathrm{~kg}$ $\mathrm{ha}^{-1}$ in semi-arid pampas of Argentina, $6 \mathrm{~kg} \mathrm{ha}^{-1}$ of wheat and $3 \mathrm{~kg} \mathrm{ha}^{-1}$ of maize in alluvial soils of northern India, $17 \mathrm{~kg} \mathrm{ha}^{-1}$ of maize in Thailand, and $10 \mathrm{~kg} \mathrm{ha}^{-1}$ of maize and $1 \mathrm{~kg} \mathrm{ha}^{-1}$ of cowpea distributed in western Nigeria [4]. A good example of 18-year experiment in Ken- 
ya showed that the yield of maize and beans was 1.4 ton $\mathrm{ha}^{-1} \mathrm{yr}^{-1}$ without external input and 6.0 ton $\mathrm{ha}^{-1} \mathrm{yr}^{-1}$ when land cover was retained and fertilizer and manure were applied. The corresponding SOC stocks to $15 \mathrm{~cm}$ depth were 23.6 tons ha $^{-1}$ and 28.7 tons ha ${ }^{-1}$, respectively [4]. Therefore, Soil C sequestration is an important strategy to achieve food security through improvement in soil quality.

\section{Uncertainties of estimating the SOC stock in Taiwan}

In order to obtain a high accuracy and great precision on estimating soil bulk density, an equation specific for each group of soils of relevance to a particular research program should be used, rather than rely on general PTFs [33]. In this study, however, available database used to develop the PTF is very limited (230 horizon-samples), whereas the database used to estimate the SOC stock is larger in sample size (19,024 soil pedons) and composed of soil from different parent materials. The PTF that we proposed here contains only two variables: SOC and the soil depth. Because of the differences of bulk density between topsoil and subsoil, PTFs based on a higher portion of subsoil samples and applied on topsoil and subsoil samples may lead to an overestimation of bulk density [36], subsequently, lead to an overestimation of the SOC stock. Besides, to estimate the SOC stock from the database of 2006, we converted the OM content to OC content by a Van Bemmelen factor of 1.724 on the assumption that SOM contains $58 \%$ of organic C averagely. Variation in the ratios of SOC to SOM in different major soil types may result in the errors of SOC stock estimation as well. Finally, quality of the legacy data and the inconsistent measurement of soil properties between independent databases are also possible sources of uncertainties for this estimation.

\section{Conclusion}

In this study, we used 184 horizon-samples to develop a pedotransfer function (PTF) for bulk density of arable soil in Taiwan. The proposed PTF is Bd $=1.3026+0.169 \log (\mathrm{d})-0.256$ $[\mathrm{Ln}(\mathrm{SOC})]^{2}$. Validation by the other 46 horizon-samples in the dataset obtained a $\mathrm{R}_{\mathrm{adj}}{ }^{2}=0.15$ and RMSE $=0.207 \mathrm{~g} \mathrm{~cm}^{-3}$. Database from soil survey by TARI in 2006 was used to estimate the SOC stock in arable soil, and soil bulk densities were estimated by the PTF that we proposed. According to our estimation, the mean SOC stock to the depth of $0-150 \mathrm{~cm}$ in arable soils is listed as the decreasing order: Tainan County $\left(12.4 \pm 5.49 \mathrm{~kg} \mathrm{~m}^{-2}\right)>$ Changhua County $\left(9.49 \pm 5.12 \mathrm{~kg} \mathrm{~m}^{-2}\right)>$ Taoyuan County $\left(8.17 \pm 4.99 \mathrm{~kg} \mathrm{~m}^{-2}\right)$. More than $30 \%$ to $80 \%$ of the total SOC stock in the upper $150 \mathrm{~cm}$ is stocked in the surface $30 \mathrm{~cm}$, depending on the soil type and soil management. Based on geostatistics and digital soil mapping techniques, we suggest that land use has great influence on the SOC stock in these arable soils. To obtain a high accuracy and great precision on estimating soil bulk density and SOC stock, databases from various soil types and PTFs for specific soils are needed in the future work. 


\section{Author details}

Chun-Chih Tsui ${ }^{1}$, Horng-Yuh Guo ${ }^{2}$ and Zueng-Sang Chen ${ }^{3 *}$

*Address all correspondence to: soilchen@ntu.edu.tw

1 Department of Agricultural Chemistry, National Taiwan University, Taiwan

2 Division of Agricultural Chemistry, Taiwan Agricultural Research Institute, Council of Agricultural, Taiwan

3 Department of Agricultural Chemistry, National Taiwan University, Taiwan

\section{References}

[1] UNFCCC. (1997). The Kyoto Protocol to the United Nations Framework Convention on Climate Change. Kyoto: UNFCCC.

[2] Batjes, N. H. (1996). Total carbon and nitrogen in the soils of the world. European Journal of Soil Science, 47(2), 151-163.

[3] Schlesinger, W. H. (1997). Biogeochemistry: An Analysis of Global Change. San Diego, California: Academic Press.

[4] Lal, R. (2004). Soil carbon sequestration impacts on global climate change and food security. Science, 304(5677), 1623-1627.

[5] Lal, R. (2008). Carbon sequestration. Philosophical Tran sactions of the Royal Society B, 363(1492), 815-830.

[6] Jansson, C., Wullschleger, S. D., Kalluri, U. C., \& Tuskan, G. A. (2010). Phytosequestration: carbon biosequestration by plants and the prospects of genetic engineering. Bioscience, 60(9), 685-696.

[7] Jenny, H. (1941). Factors of soil formation. New York: McGraw-Hill.

[8] Schlesinger, W. H. (1977). Carbon balance in terrestrial detritus. Annual Review of Ecology and Systematics, 8, 51-81.

[9] Jobbágy, E. G., \& Jackson, R. B. (2000). The vertical distribution of soil organic carbon and its relation to climate and vegetation. Ecological Applications, 10(2), 423-436.

[10] Guo, L. B., \& Gifford, R. M. (2002). Soil carbon stocks and land use change: a meta analysis. Global Change Biology, 8(4), 345-360.

[11] Murty, D., Kirschbaum, M. U. F., Mc Murtrie, R. E., \& Mc Gilvray, H. (2002). Does conversion of forest to agricultural land change soil carbon and nitrogen? A review of the literature. Global Change Biology, 8(2), 105-123. 
[12] Paul, S., Veldkamp, E., \& Flessa, H. (2008). Soil organic carbon in density fractions of tropical soils under forest-pasture-secondary forest land use changes. European Journal of Soil Science, 59(2), 359-371.

[13] Gamboa, A. M., \& Galicia, L. (2012). Land-use/cover change effects and carbon controls on volcanic ash soil profiles in highland temperate forest. Geoderma, 170, 390-402.

[14] Pandey, C. B., Singh, G. B., Singh, S. K., \& Singh, R. K. (2010). Soil nitrogen and microbial biomass carbon dynamics in native forests and derived agricultural land uses in a humid tropical climate of India. Plant and Soil, 333(1-2), 453-467.

[15] Scott, N. A., Tate, K. R., Giltrap, D. J., Smith, C. T., Wilde, R. H., Newsome, P. F. J., \& Davis, M. R. (2002). Monitoring land-use change effects on soil carbon in New Zealand: quantifying baseline soil carbon stocks. Environmental Pollution, 116(1), S167S186.

[16] Eswaran, H., Van den Berg, E., \& Reich, P. (1993). Organic carbon in soils of the world. Soil Science Society of America Journal, 57(1), 192-194.

[17] Post, W. M., \& Kwon, K. C. (2000). Soil carbon sequestration and land-use change: processes and potential. Global Change Biology, 6(3), 317-327.

[18] Lettens, S., van Orshoven, J., van Wesemael, B., Muys, B., \& Perrin, D. (2005). Soil organic carbon changes in landscape units of Belgium between 1960 and 2000 with reference to 1990. Global Change Biology, 11(12), 2128-2140.

[19] Falloon, P., Smith, P., Bradley, R. I., Milne, R., Tomlinson, R. W., Viner, D., Livermore, M., \& Brown, T. A. W. (2006). RothCUK-a dynamic modelling system for extimating changes in soil $\mathrm{C}$ from mineral soils at $1-\mathrm{km}$ resolution in the UK. Soil Use and Management, 22(3), 274-288.

[20] Knops, J. M. H., \& Tilman, D. (2000). Dynamics of soil nitrogen and carbon accumulation for 61 years after agriculture abandonment. Ecology, 81(1), 88-98.

[21] Kucharik, C. J., Brye, K. R., Norman, J. M., Foley, J. A., Gower, S. T., \& Bundy, L. G. (2001). Measurement and modelling of carbon and nitrogen cycling in agroecosystems of southern Wisconsin: Potential for SOC sequestration during the next 50 years. Ecosystems, 4(3), 237-258.

[22] Lal, R. (2004). Agricultural activities and the global carbon cycle. Nutrient Cycling in Agroecosystems, 70(2), 103-116.

[23] Lal, R., Follett, R. F., Kimble, J., \& Cole, C. V. (1999). Managing US cropland to sequester carbon in soil. Journal of Soil \& Water Conservation, 54(1), 374-381.

[24] Minasny, B., Sulaeman, Y., \& Mc Bratney, A. B. (2011). Is soil carbon disappearing? The dynamics of soil organic carbon in Java. Global Change Biology, 17(5), 1917-1924. 
[25] Pampolino, M. F., Laureles, E. V., Gines, H. C., \& Buresh, R. J. (2008). Soil carbon and nitrogen changes in long-term continuous lowland rice cropping. Soil Science Society of America Journal, 72(3), 798-807.

[26] Paustian, K., Cole, C. V., Sauerbeck, D., \& Sampson, N. (1998). CO ${ }_{2}$ mitigation by agriculture: An overview. Climatic Change, 40(1), 135-162.

[27] Jimenez, J. J., Lal, R., Leblance, H. A., Russo, R. O., \& Raut, Y. (2008). The soil C pool in different agroecosystems derived from the dry tropical forest of Guanacaste, Costa Rica. Ecological Engineering, 34(4), 289-299.

[28] Tsai, C. C., Chen, Z. S., Hseu, Z. Y., Duh, C. T., \& Guo, H. Y. (2010). Organic carbon storage and management strategies of the forest soils based on the forest soil survey database in Taiwan. In: Chen ZS, Agus F. (eds.) Proceedings of International Workshop on Evaluation and sustainable management of soil carbon sequestration in Asian countries, 28,29 September, IPB International Conference Center, Bogor, Indonesia. Food and Fertilizer Technology Center (FFTC) for the Asian and Pacific Region.

[29] Jien, S. H., Hseu, Z. Y., Guo, H. Y., Tsai, C. C., \& Chen, Z. S. (2010). Organic carbon storage and management strategies of the rural soils on the basis of Soil Information System in Taiwan. In: Chen ZS, Agus F. (eds.) Proceedings of International Workshop on Evaluation and sustainable management of soil carbon sequestration in Asian countries, 28-29September, IPB International Conference Center, Bogor, Indonesia. Food and Fertilizer Technology Center (FFTC) for the Asian and Pacific Region.

[30] Bouma, J. (1989). Using soil survey data for quantitative land evaluation. In: Stewart BA (ed.) Advances in Soil Science New York: Springer-Verlag;. , 9, 177-213.

[31] ISSS Working Group. (1998). World reference base for soil resources: Introduction. 1st edit. Acco, Leuven, the Netherlands: International Society of Soil Science, International Soil Reference and Information Centre, and Food and Agriculture Organisation of the United Nations.

[32] Tamminen, P., \& Starr, M. (1994). Bulk density of forested mineral soils. Silva Fennica, 28(1), 53-60.

[33] Harrison, A. F., \& Bocock, K. L. (1981). Estimation of soil bulk-density from loss-onignition values. Journal of Applied Ecology, 18(3), 919-927.

[34] Kaur, R., Kumar, S., \& Gurung, H. P. (2002). A pedo-transfer function (PTF) for estimating soil bulk density from basic soil data and its comparison with existing PTFs. Australian Journal of Soil Research, 40(5), 847-857.

[35] Heuscher, S. A., Brandt, C. C., \& Jardine, P. M. (2005). Using soil physical and chemical properties to estimate bulk density. Soil Science Society of America Journal, 69(1), 51-56.

[36] De Vose, B., van Meirvenne, M., Quataert, P., Deckers, J., \& Muys, B. (2005). Predictive quality of pedotransfer functions fro estimating bulk density of forest soils. Soil Science Society of America Journal, 69(2), 500-510. 
[37] Minasny, B., Mc Bratney, A. B., Mendonça-Santos, M. L., Odeh, I. O. A., \& Guyon, B. (2006). Prediction and digital mapping of soil carbon storage in the Lower Namoi Valley. Australian Journal of Soil Research, 44(3), 233-244.

[38] Suuster, E., Ritz, C., Roostalu, H., Reintam, E., Kõlli, R., \& Astover, A. (2011). Soil bulk density pedotransfer functions of the humus horizon in arable soils. Geoderma, 163(1-2), 74-82.

[39] Han, G. Z., Zhang, G. L., Gong, Z. T., \& Wang, G. F. (2012). Pedotransfer functions for estimating soil bulk density in China. Soil Science, 177(3), 158-164.

[40] Manrique, L. A., \& Jones, C. A. (1991). Bulk density of soils in relation to soil physical and chemical properties. Soil Science Society of America Journal, 55(2), 476-481.

[41] Soil Survey Staff. (1993). Soil Survey Manual. Soil Conservation Service. U.S. Department of Agriculture Handbook 18. Washington, DC., US Government Printing Office.

[42] Soil Survey Staff. (1996). Soil survey laboratory methods manual. Soil Survey Laboratory Investigations Report No.42 Washington, DC.: US Government Printing Office.

[43] Chen, C. C. (1976). Soil Survey Report of Taoyuan County. Taiwan: Taiwan Agricultural Research Institute; (in Chinese).

[44] Department of Soil, National Chung Hsing University. (1969). Soil Survey Report of Tainan County. Taiwan: Taiwan Agricultural Research Institute; (in Chinese).

[45] SAS Institute. (2008). SAS STAT user's guide. 9, Cary, NC.: SAS Institute.

[46] Chen, Y. G., \& Liu, T. K. (1991). Radiocarbon dates of river terraces along the lower Tahanchi, northern Taiwan: Their tectonic and geomorphic implications. Proceedings of the Geological Society of China, 34(4), 337-347.

[47] Wang, Y., Chen, Y., Shyu, J., Chuang, R., Lin, Y., \& Chung, L. (2002). The active tectonic features in Taoyuan Area, Northwestern Taiwan. In: Eos Transactions, American Geophysical Union 83(47) Fall Meeting Supplement, AGU2002 Fall Meeting, 6-10December, Moscone Center, San Francisco, California. San Francisco: AGU.

[48] Ho, C. S. (1988). An introduction to the geology of Taiwan explanatory text of the geologic map of Taiwan. Taipei: Central Geological Survey, Ministry of Economic Affairs.

[49] Soil Survey Staff. (1999). Soil Taxonomy: A basic system of soil classification for making and interpreting soil surveys. USDA-NRCS, Agricultural Handbook no. 436, Washington, DC.: US Government Printing Office.

[50] Chen, Z. S., \& Hseu, Z. Y. (1997). Total organic carbon pool in soils of Taiwan. Proceedings of the National Science Council, ROC-Part B: Life Science, 21(3), 120-127.

[51] Department of Soil, National Chung Hsing University. (1969). Soil Survey Report of Changhua County. Taiwan: Taiwan Agricultural Research Institute; (in Chinese). 
[52] Jacinthe, P. A., Shukla, M. K., \& Ikemura, Y. (2011). Carbon pools and soil biochemical properties in manurebased organic farming systems of semi-arid New Mexico. Soil Use and Management, 27(4), 453-463.

[53] Smith, P., Bhogal, A., Edgington, P., Black, H., Lilly, A., Barraclough, D., Worrall, F., Hillier, J., \& Merrington, G. (2010). Consequences of feasible future agricultural landuse change on soil organic carbon stocks and greenhouse gas emissions in Great Britain. Soil Use and Management, 26(4), 381-398.

[54] Wilson, B. R., Koen, T. B., Barnes, P., Ghosh, S., \& King, D. (2011). Soil carbon and related soil properties along a soil type and land-use intensity gradient, New South Wales, Australia. Soil Use and Management, 27(4), 437-447.

[55] Mchunu, C. N., Lorentz, S., Jewitt, G., Manson, A., \& Chaplot, V. (2011). No-till impact on soil and soil organic carbon erosion under crop residue scarcity in Africa. Soil Science Society of America Journal, 75(4), 1503-1512.

[56] Salomé, C., Nunan, N., Pouteau, V., Lerch, T. Z., \& Chenu, C. (2010). Carbon dynamics in topsoil and in subsoil may be controlled by different regulatory mechanisms. Global Change Biology, 16(1), 416-426. 
